RHODORA, Vol. 119, No. 979, pp. 201-211, 2017

(C) Copyright 2017 by the New England Botanical Club

doi: 10.3119/16-25; first published on-line January 4, 2018.

\title{
HEAVY METALS IN SEAWEEDS FROM A POLLUTED ESTUARY IN COASTAL MAINE
}

\author{
IAN D. Medeiros ${ }^{1}$
}

College of the Atlantic, 105 Eden Street, Bar Harbor, ME 04609

Current Address: Department of Biology, Duke University, Durham, NC 27708

${ }^{1}$ Author for Correspondence; email: ian.medeiros@duke.edu

\section{Arthur C. Mathieson}

Jackson Estuarine Laboratory, Department of Biological Sciences, University of New Hampshire, 85 Adams Point Road, Durham, NH 03824

\section{Nishanta Rajakaruna}

Biological Sciences Department, California Polytechnic State University, San Luis Obispo, CA 93407;

Unit for Environmental Sciences and Management, North-West University, Private Bag X6001, Potchefstroom, 2520, South Africa

ABSTRACT. Seaweeds (macroalgae) accumulate heavy metals from seawater and can therefore serve as biological monitors of marine pollution. In this paper, we present data on the tissue chemistry of seaweeds from the area of Callahan Mine, an intertidal copper and zinc mine in Brooksville, ME, USA, abandoned in the 1970s and now designated as a Superfund site. The mine is located on the Goose Pond estuary, which drains into the ocean via a tidal waterfall at Goose Falls. Seaweed tissue samples from this estuary had the same relative concentrations of metals as had been reported previously in water samples from this location, with $\mathrm{Zn}>\mathrm{Cu}>\mathrm{Pb}>\mathrm{Cd}$. Ascophyllum nodosum, the most common macroalgal species in the area, had comparatively high levels of all four metals in samples from Goose Pond itself, while samples from Goose Falls tended to have substantially lower metal concentrations statistically indistinguishable from samples collected in nearby unpolluted sites. At Goose Falls, where seaweed diversity was highest, Fucus distichus subsp. evanescens tended to accumulate the highest levels of $\mathrm{Zn}, \mathrm{Cu}, \mathrm{Pb}$, and $\mathrm{Cd}$. We discuss the implications of these results for the Callahan Mine environment and, more generally, for using seaweeds as biological monitors of metal pollution in coastal Maine. In an online appendix, we also provide historical and modern floristic data on the seaweeds of the Callahan Mine. The floristic and tissue chemistry data are baseline information which may be useful for the future assessment and remediation of the mine.

Key Words: Ascophyllum nodosum, cadmium, copper, lead, marine pollution, metal accumulation, Superfund sites, zinc

Habitats polluted by mining occur around the world and constitute critical areas for research on environmental contamination, monitor- 
ing, and remediation (Dudka and Adriano 1997; Thornton 1996). In coastal Maine, one such contaminated area is the former Callahan Mine, an abandoned copper and zinc mine on the eastern edge of Penobscot Bay. In the 1960s, the operators of the mine dammed and drained the Goose Pond estuary and dug an open pit for ore extraction in the middle of the drained area. When the mine was abandoned in the 1970s, the dams were removed and the estuary was re-flooded, putting an onshore tailings pond and piles of waste rock containing $\mathrm{Pb}, \mathrm{Cu}$, $\mathrm{Cd}$, and other heavy metals in close proximity to the marine environment (Ayuso et al. 2013; Broadley et al. 2013; Dwyer 1973). The mine is currently classified as a Superfund site (AMEC Environment \& Infrastructure 2015).

Previous botanical research at Callahan Mine has generated inventories of the mine's vascular plants and lichens (Mansfield et al. 2014; Medeiros et al. 2014; Rajakaruna et al. 2011) and documented metal uptake in vascular plants (Mansfield et al. 2014). The goal of the present paper is to extend this work into the marine environment. The ability of macroalgae (seaweeds) to accumulate trace metals and serve as bioindicators of metal pollution has been described in an extensive literature (e.g., Andrade et al. 2006; Engdahl et al. 1998; Fuge and James 1973; Philips 1977; Rodriguez-Figueroa et al. 2009; Rybak et al. 2012; Villares et al. 2005). This characteristic likely stems from seaweeds' inability to regulate their uptake of many trace metals (Bryan 1969; Morris and Bale 1975). In the present study, we sought to determine the species of macroalgae present in the immediate vicinity of Callahan Mine and to examine the extent to which the tissue chemistry of those species reflects the contaminants present in the mine environment.

\section{MATERIALS AND METHODS}

Site information. Callahan Mine is located on the Cape Rosier

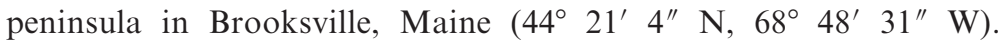
Detailed information about the history of the Mine can be found in Broadley et al. (2013) and Mansfield et al. (2014). The marine environment at Callahan Mine comprises: Goose Pond, which is the main portion of the estuary; Dyer Cove, a small cove of Goose Pond; and Goose Falls, the reversing falls at the outlet of the estuary. A map of this area is available as an online appendix (Appendix S1) at http://dx.doi.org/10.6084/m9.figshare.4270190.

Sample collection. Samples for metal analyses were collected by IDM and NR during late March 2015 and early April 2016. Seaweed 
samples were collected at the following locations within the Callahan Mine area: the inland side of Goose Falls, the southern shoreline of Goose Pond, and the shoreline of Dyer Cove. Collections of Ascophyllum nodosum (L.) Le Jolis were also made along the shorelines of Smith Cove and Buck's Harbor, "clean" sites east of the Mine (Appendix S1). Specimens were collected from the intertidal and shallow subtidal zones. Seaweeds were identified with VillalardBohnsack (1995). Nomenclature follows Guiry and Guiry (2016).

Sample preparation. Seaweed specimens were stored in plastic bags and refrigerated until they could be cleaned. Samples were first rinsed in deionized water or tap water. Epiphytic algae were removed by scraping the thallus with forceps or a scalpel. Samples were then bathed in a solution of $10 \%$ ethanol and $3.5 \% \mathrm{NaCl}$, followed by two baths in deionized water. The seaweed tissue was gently scrubbed during these baths. This is fundamentally the same cleaning procedure shown by Gledhill et al. (1998) to be the most effective method for removing metal particulate contaminants from macroalgae prior to tissue chemistry assays. Cleaned samples were dried in an oven at $60-70^{\circ} \mathrm{C}$ for 48 hours.

Elemental analysis. All analyses were carried out at the Maine Agricultural and Forest Experiment Station Analytical Laboratory, University of Maine, Orono. Dried seaweed tissue was ground in a mortar and pestle and ashed at $350^{\circ} \mathrm{C}$. The ash was dissolved in $50 \%$ $\mathrm{HCl}$ on a hotplate, and concentrations of $\mathrm{Al}, \mathrm{B}, \mathrm{Ca}, \mathrm{K}, \mathrm{Mg}, \mathrm{Mn}, \mathrm{P}, \mathrm{Fe}$, $\mathrm{Cu}, \mathrm{Cd}, \mathrm{Zn}$, and $\mathrm{Pb}$ were measured with Inductively Coupled Plasma Spectroscopy (ICP-OES; Thermo Scientific, Tewksbury, MA). For two samples of Ascophyllum nodosum, As was measured with tissue digestion by EPA Methods 3051 and 3010 and elemental analysis by EPA Method 7061 A and $\mathrm{Hg}$ was measured with tissue digestion by EPA Method 3051 and elemental analysis by EPA Method 7471A.

Statistical analysis. Metal concentrations were compared between species and sites using one-way ANOVA with the Tukey-Kramer test. This analysis was conducted in Python with the statsmodels module (Seabold and Perktold 2010).

\section{RESULTS}

Goose Pond proper has a shallow, sloping intertidal zone covered by fine sediments and small cobbles. Ulva intestinalis L. is abundant in this zone, and stunted individuals of Ascophyllum nodosum and Fucus vesiculosus $L$. are common. Dyer Cove, which has a steeper and more 
rocky intertidal zone, hosts larger individuals of A. nodosum and $U$. intestinalis. Water movement at both Goose Pond and Dyer Cove is very slow. At Goose Falls, which has a rocky intertidal zone, Ascophyllum nodosum and Fucus spp. (mainly Fucus distichus subsp. evanescens (C. Agardh) H. T. Powell) dominate the intertidal zone, while the main channel (shallow subtidal zone) supports Saccharina latissima (L.) C. E. Lane et al., Desmarestia viridis (O. F. Muller) J. V. Lamouroux, Halosiphon tomentosus (Lyngbye) Jaasund, and other species growing in the fast-flowing current.

Tissue metal assays were obtained for whole thalli of Ascophyllum nodosum ( $\mathrm{n}=16)$, Dumontia contorta (S. G. Gmelin) Ruprecht $(\mathrm{n}=4)$, Halosiphon tomentosus $(\mathrm{n}=3)$, Ulva intestinalis $(\mathrm{n}=5$, each sample comprising all of the thalli growing in a palm-sized area), Fucus spp. ( $F$. vesiculosus, $\mathrm{n}=3$ and $F$. distichus subsp. evanescens, $\mathrm{n}=4$ ), Desmarestia viridis $(\mathrm{n}=3)$, and Saccharina latissima $(\mathrm{n}=6)$. Complete tissue chemistry data are available in an online appendix (Appendix S2) at http://dx.doi.org/10.6084/m9.figshare.4270202; this appendix includes data for additional chemical elements not discussed in this paper. Three additional species-Scytosiphon lomentaria (Lyngbye) Link, Monostroma grevillei (Thuret) Wittrock, and Hildenbrandia rubra (Sommerfelt) Meneghini-were observed at Goose Falls but not found in sufficient quantity for tissue analysis. We attempted to assay tissue of the epiphyte Elachistea fucicola (Velley) Areschoug, which was abundant on A. nodosum and Fucus spp. at the study site. However, it proved impossible to adequately clean particulate matter from these samples, as evidenced by $\mathrm{Fe}$ and $\mathrm{Pb}$ levels an order of magnitude above anything else we sampled.

Tissue chemistry of Ascophyllum nodosum is compared across multiple sites in Figure 1. Ascophyllum nodosum from Dyer Cove and from Goose Pond proper contain more $\mathrm{Cu}$ than material of the same species from Goose Falls, while samples from other nearby, "clean" areas had $\mathrm{Cu}$ levels that were even lower, below the detection limit of the equipment used for analysis. Levels of $\mathrm{Zn}$ in A. nodosum declined dramatically from Dyer Cove to the clean sites. $\mathrm{Cd}$ and $\mathrm{Pb}$ were detected in A. nodosum from Dyer Cove and Goose Pond but were undetectable or barely detectable in A. nodosum at Goose Falls or the clean sites (Figure 1).

In Goose Cove, levels of all four metals tended to be somewhat higher in Fucus vesiculosus than in Ascophyllum nodosum. Ulva intestinalis, an annual species, tended to have lower metal concentrations than $F$. vesiculosus or A. nodosum, both perennials (Appendix S2). 

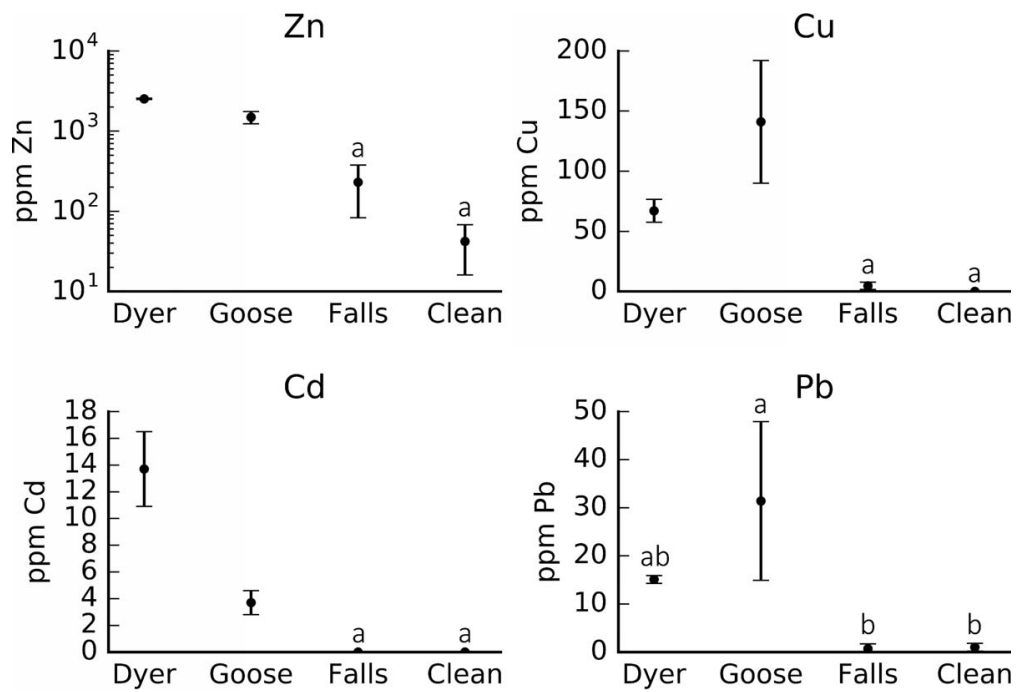

Figure 1. Levels of $\mathrm{Zn}, \mathrm{Cu}, \mathrm{Cd}$, and $\mathrm{Pb}$ in Ascophyllum nodosum in the Callahan Mine area. Note that $\mathrm{Zn}$ values are plotted on a logarithmic scale, while values for the other metals are plotted on linear scales. Dyer $=$ Dyer Cove $(\mathrm{n}=3)$; Goose $=$ Goose Pond $(\mathrm{n}=4)$; Falls $=$ Goose Falls $(\mathrm{n}=5)$; Clean $=$ Smith Cove and Bucks Harbor $(n=4)$. Error bars show one standard deviation. Shared letters indicated that the difference between two sites is not statistically significant (ANOVA with Tukey-Kramer test, $\mathrm{p}>0.05$ ).

Goose Falls hosted the greatest diversity of seaweeds in the study area; tissue metal contents of six different species at this location are compared in Figure 2. Fucus distichus subsp. evanescens had the highest levels of all four metals of interest, albeit with large standard deviations. For the other five species (Ascophyllum nodosum, Halosiphon tomentosus, Desmarestia viridis, Saccharina latissima, and Dumontia contorta), levels of $\mathrm{Pb}$ were similar and $\mathrm{Cd}$ levels were not detectable.

Floristic collections made at Callahan Mine by ACM during the 1990s (as part of the fieldwork for Mathieson et al. 1996) are detailed in an online appendix (Appendix S3) available at http://dx.doi.org/10.6084/m9.figshare.4270247.

\section{DISCUSSION}

Broadley et al. (2013) analyzed water samples from several points in Goose Pond. They found that concentrations of $\mathrm{Cd}, \mathrm{Pb}$, and $\mathrm{Zn}$ from 

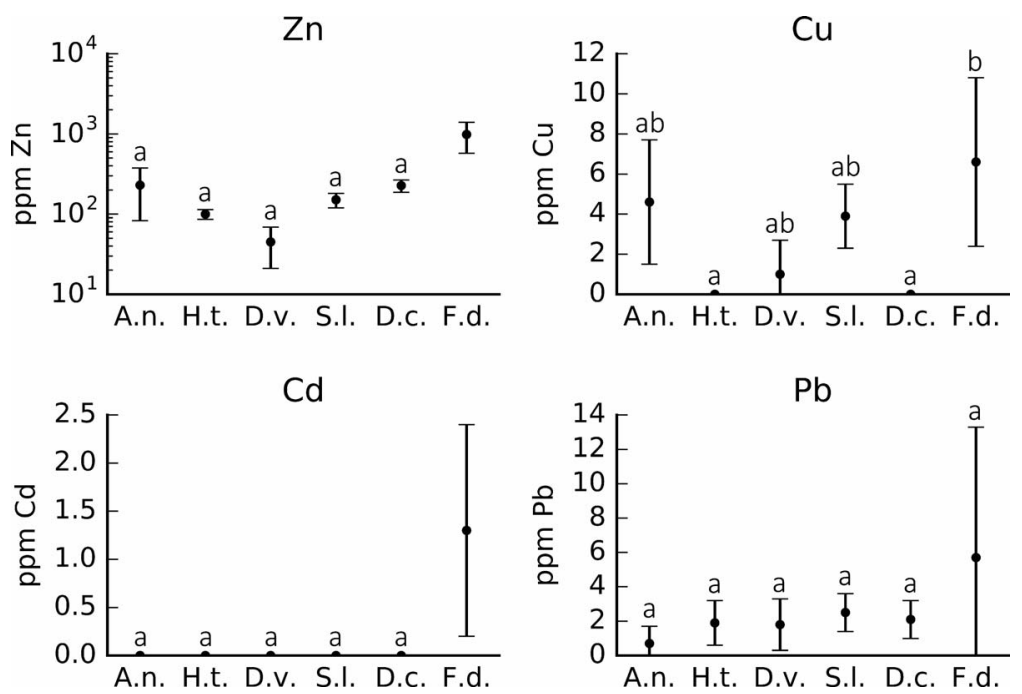

Figure 2. Levels of $\mathrm{Zn}, \mathrm{Cu}, \mathrm{Cd}$, and $\mathrm{Pb}$ in six different macroalgae at Goose Falls. Note that $\mathrm{Zn}$ values are plotted on a logarithmic scale, whereas values for the other metals are plotted on linear scales. A.n.=Ascophyllum nodosum $(\mathrm{n}=5)$; H.t. = Halosiphon tomentosus $(\mathrm{n}=3) ;$ D.v. $=$ Desmarestia viridis $(\mathrm{n}=3) ;$ S.1. $=$ Saccharina latissima $(\mathrm{n}=6) ;$ D.c. $=$ Dumontia contorta $(\mathrm{n}=4) ;$ F.d. = Fucus distichus subsp. evanescens $(\mathrm{n}=3)$. Error bars show one standard deviation. Shared letters indicated that the difference between two species is not statistically significant (ANOVA and Tukey-Kramer test, $\mathrm{p}>0.05$ ).

Goose Falls were significantly lower than those from Dyer Cove. $\mathrm{Cu}$ concentrations at these two spots were statistically indistinguishable due to the large standard deviation of the Goose Falls values. Concentrations of $\mathrm{Cu}, \mathrm{Cd}, \mathrm{Pb}$, and $\mathrm{Zn}$ from Goose Falls were higher than metal concentrations at the nearby, unpolluted Horseshoe Cove, but this difference was not statistically significant for $\mathrm{Zn}$ or $\mathrm{Pb} . \mathrm{Cu}$ and $\mathrm{Cd}$ concentrations at this "clean" site were below the detection limit of the equipment used for analysis.

The chemistry of algal tissue from around Goose Pond reflects these differences. Ascophyllum nodosum samples from Goose Pond and Dyer Cove, which are closer to the sources of pollution and likely experience less water turnover than the outlet of the estuary, have higher levels of all four metals than samples of the same species from Goose Falls or nearby clean areas (Figure 1).

In the water samples assessed by Broadley et al. (2013), the concentrations of metals consistently followed a trend of $\mathrm{Zn}>\mathrm{Cu}>$ 
$\mathrm{Pb}>\mathrm{Cd}$. This makes sense given that $\mathrm{Cu}$ and $\mathrm{Zn}$ were the primary targets of mining at Callahan Mine. Our seaweed samples tended to follow the same pattern, although the concentrations of metals in algal tissue were on the order of parts per million instead of the parts per billion found in water. Broadley et al. (2013) measured the concentration of $\mathrm{Zn}$ in the water of Dyer Cove to be approximately $40 \mathrm{ppb}$. The concentration of $\mathrm{Zn}$ in algal tissue from Dyer Cove was much higher, averaging at about $300 \mathrm{ppm}$ for Ulva intestinalis and 2500 ppm for Ascophyllum nodosum. These results show that the macroalgae of this heavily polluted area appear to accumulate metals rather than simply absorbing them at the background level. Concentrations of $\mathrm{Zn}$, $\mathrm{Cu}$, and $\mathrm{Pb}$ in the seaweeds of Callahan Mine are also much higher than the metal concentrations Ayuso et al. (2013) found in crabs in Goose Pond and lobsters directly outside Goose Falls. Cd was not measured in that study.

Ascophyllum nodosum samples from Goose Falls had a higher level of $\mathrm{Zn}$ than samples from the clean sites, although this difference was not statistically significant. On the other hand, results for other metals did not even suggest a difference between Goose Falls and the clean sites (Figure 1). Ascophyllum nodosum at the outlet of Goose Pond had an average $\mathrm{Cu}$ content of about $5 \mathrm{ppm}$; in comparison, a study in Atlantic Canada which looked at algae not associated with particularly polluted areas found $A$. nodosum to have an average $\mathrm{Cu}$ content of 6 ppm (Young and Langille 1958). Similarly, Fucus vesiculosus samples in that study had an average $\mathrm{Cu}$ content of 8 ppm, while Fucus distichus subsp. evanescens samples from Goose Falls had an average $\mathrm{Cu}$ content of about $7 \mathrm{ppm}$ (Figure 2). The concentrations of heavy metals in algal tissue from Dyer Cove and Goose Pond are substantially higher than those reported in some other studies of polluted areas (e.g., RodriguezFigueroa et al. 2009), but the concentrations of some metals at Goose Falls are substantially lower than what is seen in much of the relevant literature.

Although the data clearly show that metal pollution from Callahan Mine affects the tissue chemistry of several seaweeds species in the vicinity of the mine, the fact that tissue metal levels in this estuary are higher on the inland shore than at the outlet suggests that the metal pollution caused by Callahan Mine probably does not have substantial effects on intertidal seaweeds outside the Goose Pond estuary. This is good news from both human health (Besada et al. 2009) and environmental health perspectives. Goose Falls appears to support a diverse algal biota (Appendix S3) showing no obvious signs of damage from metal pollution; fast-moving tidal currents (e.g., tidal waterfalls) 
tend to support higher algal diversity than contiguous quiescent areas (Mathieson et al. 1983; Reynolds and Mathieson 1975). These same currents may ameliorate the effects of metal pollution on the algae at Goose Falls.

We do not have floristic data of sufficient temporal resolution to determine why certain species that were documented from Goose Falls by Collins (1899) - such as Bryopsis plumosa, Alaria esculenta, or Gloiosiphonia capillaris - are no longer present. Two possible explanations are metal pollution from the Mine or changes in water flow when the estuary was dammed, but without collections from the 1960s and 1970s it is impossible to know if either hypothesis is correct.

In terms of the future monitoring of the Callahan Mine, our study provides baseline data for both seaweed diversity and tissue chemistry. The species assayed in this study could be collected and assayed in the future to evaluate the effects of remediation projects on the local marine environment. For such an investigation, whole thalli of annual species (such as Ulva intestinalis) or the youngest tissue of perennial species (such as the tips of Ascophyllum nodosum or the blade base of Saccharina latissima) might provide the most appropriate indicators of current conditions. More broadly, our tissue chemistry data suggest that common intertidal and shallow subtidal species (the species assayed for this study are all common seaweeds in the Penobscot Bay region according to Mathieson et al. 1996) could be used for the assessment of metal contamination in marine habitats of coastal Maine. At any appreciable distance from the known pollution source, Fucus species would seem to be the best choice for detecting trace metals, although a large number of samples should be collected due to the high variability we observed in Fucus tissue chemistry (Figure 2). Closer to the source of pollution, more taxa could be sampled, including the ubiquitous Ascophyllum nodosum.

Given the unique circumstances of the Callahan Mine, one final question could be asked: Is there any potential for seaweeds to be utilized in the remediation of this site? Researchers (e.g., Mwangi and Ngila 2012) have used activated seaweed biomass as an absorbent material for heavy metals, but little work has been done on actual "phycoremediation" with living macroalgae. It is possible that a longterm effort with annual species on an artificial substratum could play a role in the remediation of the Goose Pond estuary. The efficacy of such an approach, however, would need to be assessed through further experimentation and is not something on which we can speculate here. 
Contributions: Conceptualization, IDM; Methodology, IDM and NR; Investigation, IDM, ACM, Suzanne Perron (University of Maine Analytical Laboratory), and NR; Writing-Original Draft, IDM; Writing-Review \& Editing, IDM, NR, and ACM; Visualization, IDM; Supervision, NR; Funding Acquisition, IDM and NR.

ACKNOWLEDGMENTS. Funding for this project was provided by a Maine Sea Grant to IDM and NR and by a grant from the Salisbury Cove Research Fund to College of the Atlantic. Lea Savarese (College of the Atlantic) helped clean algal tissue samples. We thank Dr. Paul Silva, University of California, Berkeley (deceased), who provided a Xerox copy of F. S. Collins' field note book that documented historical record of seaweeds from the Callahan Mine area. Two anonymous reviewers and Don Padgett (Bridgewater State University) provided comments and critiques that substantially improved the paper. Published as contribution number 560 from UNH's Jackson Estuarine Laboratory.

\section{LITERATURE CITED}

AMEC EnVironment \& Infrastructure, Inc. 2015. OU3 final remedial design basis of design report: Callahan Mine superfund site, Brooksville, Maine. Report prepared for Maine Department of Transportation. Available online at https://semspub.epa.gov/work/01/581498.pdf, accessed 29 November 2016.

Andrade, S., M. H. Medina, J. W. Moffett, and J. A. Correa. 2006. Cadmium-copper antagonism in seaweeds inhabiting coastal areas affected by copper mine waste disposals. Environm. Sci. Technol. 40: $4382-4387$.

Ayuso, R. A., N. K. Foley, R. R. Seal, M. Bove, D. Civitillo, A. Cosenza, AND G. Grezzi. 2013. Lead isotope evidence for metal dispersal at the Callahan $\mathrm{Cu}-\mathrm{Zn}-\mathrm{Pb}$ mine: Goose Pond tidal estuary, Maine, USA. J. Geochem. Explorat. 126: 1-22.

Besada, V., J. M. Andrade, F. Schultze, and J. J. Gonzalez. 2009. Heavy metals in edible seaweeds commercialised for human consumption. J. Mar. Syst. 75: 305-313.

Broadley, H. J., K. L. Buckman, D. M. Bugge, and C. Y. Chen. 2013. Spatial variability of metal bioaccumulation in estuarine killifish (Fundulus heteroclitus) at the Callahan Mine Superfund site, Brooksville, ME. Arch. Environm. Contam. Toxicol. 65: 765-778.

Bryan, G. W. 1969. The absorption of zinc and other metals by the brown seaweed Laminaria digitata. J. Mar. Biol. Assoc. U.K. 49: 225-243.

Collins, F. S. 1899. A seaweed colony. Rhodora 1: 69-71.

DudKa, S. AND D. C. Adriano. 1997. Environmental impacts of metal ore mining and processing: A review. J. Environm. Qual. 26: 590-602. 
DWyer, R. L. 1973. The relation between heavy metal effluents and benthic infaunal community changes in a coastal embayment in Maine. M.Sc. thesis, Massachusetts Institute of Technology, Cambridge, MA, USA.

Engdahl, S., F. Mamboya, M. Mtolera, A. Semesi, and M. Buork. 1998. The brown macroalgae Padina boergesenii as an indicator of heavy metal contamination in the Zanzibar Channel. Ambio 27: 694-700.

Fuge, R. And K. H. James. 1973. Trace metal concentrations in brown seaweeds, Cardigan Bay, Wales. Mar. Chem. 1: 218-293.

Gledhill, M., M. T. Brown, M. Nimmo, R. Moate, and S. J. Hill. 1998. Comparison of techniques for the removal of particulate material from seaweed tissue. Mar. Environm. Res. 45: 295-307.

Guiry, M. D. And G. M. Guiry. 2016. AlgaeBase. World-wide electronic publication, National University of Ireland, Galway. http://www. algaebase.org; searched on 13 August 2016.

Mansfield, M. R., N. S. Pope, G. H. Mittelhauser, and N. Rajakaruna. 2014. Diversity and soil-tissue elemental relations of vascular plants of Callahan Mine, Brooksville, Maine, USA. Rhodora 116: 283-322.

Mathieson, A. C., E. J. Hehre, J. Hambrook, and J. Gerweck. 1996. A comparison of insular seaweed floras from Penobscot Bay, Maine, and other northwest Atlantic islands. Rhodora 98: 369-418.

- C. D. Neefus, and C. Emerich-Penniman. 1983. Benthic ecology in an estuarine tidal rapid. Bot. Mar. 16: 213-230.

Medeiros, I. D., A. M. Fryday, and N. Rajakaruna. 2014. Additional lichen records and mineralogical data from metal-contaminated sites in Maine. Rhodora 116: 323-347.

Morris, A. W. And A. J. Bale. 1975. The accumulation of cadmium, copper, manganese and zinc by Fucus vesiculosus in the Bristol Channel. Estuar. Coast. Mar. Sci. 3: 153-163.

Mwangi, I. W. and J. C. NGila. 2012. Removal of heavy metals from contaminated water using ethylenediamine-modified green seaweed (Caulerpa serrulata). Phys. Chem. Earth 50-52: 111-120.

Philips, J. H. 1977. The use of biological indicator organisms to monitor trace metal pollution in marine and estuarine environments-a review. Environm. Pollut. 13: 281-317.

Rajakaruna, N., T. B. Harris, S. R. Clayden, A. C. Dibble, and F. C. Olday. 2011. Lichens of the Callahan mine, a copper-and zinc-enriched superfund site in Brooksville, Maine, USA. Rhodora 113: 1-31.

Reynolds, N. B. ANd A. C. Mathieson. 1975. Seasonal occurrence and ecology of marine algae in a New Hampshire tidal rapid. Rhodora 77: 512-533.

Rodriguez-Figueroa, G. M., E. Shumilin, and I. Sanchez-Rodriguez. 2009. Heavy metal pollution monitoring using the brown seaweed Padina durvillaei in the coastal zone of the Santa Rosalıa mining region, Baja California Peninsula, Mexico. J. Appl. Phycol. 21: 19-26.

Rybak, A, B. Messyasz, AND B. Łeska. 2012. Freshwater Ulva (Chlorophyta) as a bioaccumulator of selected heavy metals $(\mathrm{Cd}, \mathrm{Ni}$ and $\mathrm{Pb})$ and alkaline earth metals (Ca and $\mathrm{Mg}$ ). Chemosphere 89: 1066-1076. 
Seabold, S. and J. Perktold. 2010. Statsmodels: Econometric and Statistical Modeling with Python. pp. 57-61. In: S. van der Walt and J. Millman, eds., Proceedings of the 9th Python in Science Conference (SCIPY 2010). 28 June-3 July 2010, Austin, Texas. ISBN-13: 978-1-4583-4619-3.

Thornton, I. 1996. Impacts of mining on the environment; some local, regional and global issues. Appl. Geochem. 11: 355-361.

Villalard-Bohnsack, M. 1995. Illustrated key to the seaweeds of New England. Rhode Island Natural History Survey, Kingston, RI, USA.

Villares, R., E. Carral, X. Puente, and A. Carballeira. 2005. Metal levels in estuarine macrophytes: Differences among species. Estuaries 28: 948-956.

Young, E. G. AND W. M. LANGiLle. 1958. The occurrence of inorganic elements in marine algae of the Atlantic provinces of Canada. Canad. J. Bot. 36: $301-310$. 
Copyright of Rhodora is the property of Allen Press Publishing Services Inc. and its content may not be copied or emailed to multiple sites or posted to a listserv without the copyright holder's express written permission. However, users may print, download, or email articles for individual use. 